could be a detector of such 'influences' if they existed. But there are also now extensive reports of wellcontrolled experiments that give evidence of a quite different kind that there is a two-way traffic between mind and the matter-energy system. Of particular significance for the above hypothesis of mind influence on brain are the psycho-kinetic experiments ${ }^{26}$. These experiments as described leave little room for doubt that very slight changes can be produced by some minds on moving physical objects such as dice, effects which are revealed only when statistical analysis is applied to relatively long series of trials. In particular, the striking decline in effectiveness with time would seem to exclude all physical factors. There are, too, the even better authenticated experiments of the complementary process called extrasensory perception ${ }^{26,27}$. If these experiments are revealing facts, there is an interaction of physical events with mind, as indeed is also indicated above by Eddington's second hypothesis. If as men of science we reject these experiments, it should be done on the basis of established errors in their execution or interpretation. Such errors have evaded years of careful scrutiny by unsympathetic critics. It will be agreed with Rhine ${ }^{26}$ that, if the so-called psi-capacities (psycho-kinesis and extrasensory perception) exist, they provide evidence of slight and irregular effects which are precisely of the nature that must be postulated for brain-mind liaison, but which occur there in highly developed form. The present hypothesis would offer an explanation for this high development of matter-mind traffic in the active human cerebral cortex, the development including not only continuous operation but also exquisite subtlety in transmission. Both these features would receive explanation on the basis of the interlocking, integrating and ever-changing pattern of activity formed by the multiple (ten thousand million-fold) detectors that exist in the cortex during consciousness.

1 Burtt, E. A., "The Metaphysical Foundations of Modern Physical Science" (Kegan Paul, 1925)

2 Stout, G. F., "Mind and Matter" (Cambridge, 1931).

${ }^{3}$ Ryle, G., "The Concept of Mind" (Hutchinson's University Library, 1949).

4Eddington, A., "The Philosophy of Physical Science" (Cambridge, 1939).

5 Sherrington, C. S. "Man on his Nature" (Cambridge, 1940).

"Adrian, E. D., "The Physical Background of Perception" (Oxford, 1947)

"Adrian, E. D., in "The Physical Basis of Mind", edited by P. Laslett (Blackwell, 1950).

Bremer, F., E.E.G. Clin. Neurophysiol., 1, 177 (1949),

- Burns, B. D., J. Physiol., 111, 50 (1950).

${ }^{10}$ Burns, B. D., J. Physiol., 112, 156 (1951).

11 Blake, H., Gerard, R. W., and Kleitman, N., J. Neurophysiol., 2, 48 (1939).

12 Brazier, M. A. B., J. Neurol. Neurosurg. Psych., 11, 118 (1948).

1s Cobb, W. A., in "Electroencephalography", edited by D. Hill and G. Parr (Macdonald, 1950).

${ }^{14}$ Lashley, K. S., in "Physiologieal Mechanisms in Animal Behaviour" (Cambridge, 1950)

${ }^{15}$ Eccles, J. C., and McIntyre, A. K., Nature, 167, 466 (1951).

I6 Lorente de No, R., J. Psych. Neurol. 45, 381 (1933).

17 Lorente de No, R., J. Psych. Neurol., 46, 113 (1934).

1s Lorente de No, R., in "Physiology of the Nervous System", by J. F. Fulton (Oxford, 1943)

Whitteridge, D., in "Electroencephalography", editcd by D. Hill and G. Parr (Macdonald, 1050).

${ }^{20}$ Eccles, J. C., Arch. Sci. Physiol., 3, 567 (1949).

21 Eccles, J. C., Brit. Med. Bull., 6, 304 (1950).

${ }^{22}$ Renshaw, B., Forbes, A., and Morison, B. R., J. Neurophysiol., 3, $74(1940)$.

${ }^{28}$ Adrian E. D., J. Physiol., 88, 127 (1936).

${ }^{24}$ Thompson, H. B., J. Comp. Neurol., 9, 113 (1899),

${ }^{25}$ Haggar, R. A., and Barr, M. L., J. Comp. Neurol., 93, 17 (1950).

${ }^{26}$ Rhine, J. B., "The Reach of the Mind" (Faber, 1948).

${ }_{27}$ Soal, S. G., Hibbert J., 48, 231 (1950).

\section{THE WEST AUSTRALIAN FLORA*}

\section{By SIR EDWARD SALISBURY, C.B.E., F.R.S.}

$\mathrm{N}$ order to appreciate the character of the Australian 1 flora it is necessary to realize first of all the influence of the extent of this vast continent isolated by large stretches of ocean from the nearest land mass. The localized distribution in Australia of large centres of population is a sufficient indication of the markedly peripheral distribution of situations favourable to human activity. Indeed, it is true that only about 15 per cent of the total of nearly three million square miles, which is approximately the area of Australia, has a rainfall of more than thirty inches, and this has to be considered in relation to the high and sometimes very excessive summer temperature. Furthermore, the average rainfall data in Australia are perhaps even more misleading than most averages, for nearly half Australia has a rainfall variability of 40-50 per cent, and even in the more habitable parts a variability of 20 per cent is by no means infrequent. In other words, the greater part of Australia is arid for a shorter or lengthier period, and the more arid region, abutting as it does upon the north of the Great Bight which reaches to the Nullabor Plain, means that Western Australia is isolated on the east by thousands of miles of desert as effectively as it is on the west by thousands of miles of ocean. Thus Western Australia is only capable of supporting in its central region specialized vegetation of an extreme xerophyllous type. Western Australia is, in fact, almost isolated from all the most favourable areas for vegetable growth except for its own southwest corner, where temperate rain-forest occurs.

A further point of some importance is that many of the soils in the southern and central parts are comparatively recent. In common with the most favourable areas for vegetation, the geologically ancient areas are likewise marginal. It is therefore scarcely surprising, when we consider all these facts together, that we find the flora of Western Australia is as a whole, like other isolated areas of far smaller extent, characterized by the high proportion of endemics which it comprises, amounting to about 85 per cent of the total.

Nevertheless, despite the isolation of Australia as a whole and of Western Australia in particular, the flora shows affinities with those of South America and South Africa. The facile explanation that some authorities have favoured that the former Antarctic Continent provided land connexions for the migration of a common flora between Australia, South America and South Africa would appear to be an anachronism of wishful thinking, since there is no evidence that the flowering plants, as we understand that group to-day, were differentiated until long after such land connexions had ceased to exist, and indeed the extensive Cretaceous transgression of the ocean that rendered the separation of these areas probably much greater than to-day occurred about the time that the Angiosperms perhaps evolved.

One family, rich in endemics, that is especially a feature of Western Australia, is the Myrtaceæ. Members of this family have a wide distribution in warm regions, but the genus Eucalyptus with some three hundred species is almost confined to Australia with many species only found in the west, and one of the most beautiful of these endemics is Eucalyptus macrocarpa, * Substance of a Friday evening discourse delivered at the Royal Institution on May 18. 
with large red flowers. Other striking members endemic to Western Australia are the Geraldtown wax flower (Chamcelaucium), and above all the beautiful fringe flowers (Verticordia) which adorn with their dainty blossoms the arid sandy heaths of the West where more than three-quarters of the forty known species are alone to be found. They owe their name to the fringe-like sepals, and in some species the petals are dissected also. The genus Calothamnus comprising twenty-five species is entirely Western Australian, and all these exhibit leaves highly resistant to desiccation.

The Proteacere is one of the most characteristic families of the Australian flora, and this group would appear to have had a wide distribution in Tertiary times. Although many of the so-called proteaceous fossil leaves are of dubious attribution, there seems little doubt that the family was formerly represented in the northern hemisphere, as the late Sir Albert Seward, after a critical assessment of the evidence, concluded. Moreover, recent studies in Australia have shown that the family even there had a more extensive distribution than to.day. The present geographical range is wide over the southern hemisphere but discontinuous, with concentrations in South Africa and Australia; but by far the largest number of endemic species are located in Western Australia. It is therefore difficult to escape the conclusion that this is an ancient family that has experienced a diminishing range and increasing differentiation through the past thirty million years of its history. It is a specialist family peculiarly fitted for growth in conditions of great seasonal aridity and correspondingly unfitted for competition with the more vigorous and faster growing types in conditions more favourable to plant growth. Thas the increasing restriction of this family is probably to be attributed to ecological causes : the climatic differentiation of recent epochs which, combined with soil development, have produced localized areas that constitute the sanctuaries for its survival.

Of the total of fifty genera in this family it is true that only five are confined to Western Australia, the most important being the genus Dryandra, with some fifty members, but altogether more than 370 species of Proteacex, or almost two-fifths of the entire family, are restricted to this area.

The foliage of the Western Australian proteaceous trees and shrubs is uniformly leathery in texture, but may be needle-like and unbranched as in some species of Hakea, or broad and flat as the leaves of Banksia menziesii; but, in all, the foliage shows but little change when dried. This is due to the rigid interior skeleton and robust epidermis, which offer a great mechanical resistance to desiccation. The surface is covered with a thick cuticle almost impervious to water vapour, and the stomata are usually sunk in pits and often protected by perforated domes of cuticle which diminish the effect of hot, dry winds. It is noteworthy that a branch of Dryandra that has been detached from the plant for more than a year retains the form of its leaves almost unaltered, thus bearing witness to the mechanical resistance to shrinkage and so to loss of water vapour.

It is this same adaptation to drought conditions that is doubtless responsible for the striking similarity of growth habit which is often exhibited by species of different genera and families. I was much impressed by this feature in a heath-like area of scrub towards the edge of the Nullabor Plain, where the average rainfall was between 10 and $15 \mathrm{in.}$ per annum.
Here members of a number of families showed a marked similarity of vegetative structure sometimes so close as to render them almost indistinguishable, except by the expert, when not in flower. Such epharmony is particularly well exemplified by the ericoid habit, not only shown as we should expect by the Epacridaceæ but also by Hibbertia hypericoides (Dilleniaceæ), Leschenaultia formosa (Goodeniaceæ), Boronia megastigma and Thryptomera sp. (Myrtaceæ), Acacia rossii (Leguminosx), Erremoxhila (Myopocaceæ), Petrophila ericifolia (Proteaceæ), and even by the Liliaceæ in that remarkable shrub Calectaria cyanea, to mention but one representative from seven different families; but this list could be extended almost ad nauseam.

Again, the switch-like habit in which the leaves have undergone extreme reduction is paralleled in a number of quite unrelated species. Examples are furnished by the phyllodic species of Acacia, where the function of the leaves is assumed by green modified leaf stalks or flattened stems; and by the she oaks (Casuarina), looking like woody horsetails with minute leaves on green longitudinally grooved stems, these grooves providing shelter for the stomata, which are further protected by the presence of hairs. The Restionaceæ is a particularly characteristic Australian family, where the stems also perform the function of leaves.

Alike in these plants the assumption of the leaf function by stem or leaf-stalk has resulted in an increase of mechanical resistance to water-loss and thus in a prolongation of photosynthetio activity.

The shelter afforded by a felt-like covering of woolly hairs which protects the surface of the plant from direct wind action is well exemplified in the Verbenaceous genus Lachnostachys, aptly known by the popular name of lamb's tails. Here the white appearance, which the air-filled hairs confer, bears witness to the large amount of the incident light which is reflected and thus enhances the protection. that the hairs afford. As a second example mention may be made of the flannel flowers (Actinotis sp.), which belong to the Umbelliferæ and recall the edelweiss of the European flora.

The succulent habit is not commonly represented except in the saline areas, where perennial members of the Chenopodiaceæ such as Salicornia australis are frequent and exhibit this feature, as also annual species of Zygophyllum.

The extreme habitat conditions call forth a similar adaptation for resistance to water loss in such an unlikely group as the Liliaceæ. The Western Australian representatives of this family includes two arboreal genera, namely, the blackboys, Xanthorrhoea, and the grass tree, Kingia australis. These both heve long grass-like leaves internally supported by sclerotic tissue. In the triangular or quadrangular leaves of the blackboys there is a thick investment of woody tissue just beneath the surface that resists shrinkage. In Kingia there are in addition internal woody bands that augment the resistance to shrinkage and thus to the escape of water vapour. It should perhaps be emphasized, what is too often overlooked, that the so-called transpiration checks are mainly of importance as prolonging the period of photosynthetic activity and thus fulfil their purpose, even if the leaf eventually wilts or even dies. In order to emphasize that death may not result from extreme desiccation my own experience with Kochia tomentosa, one of the Western Australian salt-bushes, is worth recording. I gathered a piece of this plant and, being uncertain of its identity, retained a small sprig and placed this 
in my pocket-book, where it remained in a very dry and brittle condition for three weeks while $\dot{I}$ was travelling by a roundabout route to Adelaide via Melbourne and the Murray Valley. It was then packed up with some papers and dispatched to England, where it remained in a centrally heated room for some months. Then taken out, it was inadvertently placed on the top of a cupboard in an unheated room during a spell of foggy weather. When found a week later it had put out some small shoots of diminutive new leaves. What osmotic suction it had attained I hesitate to guess.

The so called protocorm of that unique Australian lycopod, Phylloglossum drummondii, to which such importance was attached during the phylogeny hunting of the early years of this century is probably only biologically significant as presenting another adaptation to an intermittently arid environment that we see so strikingly developed in the tuberous sundews. British sundews, which grow in permanently damp places, have a meagre root system, but these Australian sundews, which grow in areas that are under water in winter but become dry and arid sandy wastes in summer, seem invariably to possess an underground tuber two to six inches beneath the surface according to the species. From such a hard round tuber arise the long stems of the climbing species that deck the branches with their glistening leaves and bear at the summit large white, pink or even yellow flowers. The sundews are particularly well represented and very diverse in character. Drosera macrophylla has a rosette of large leaves which together with the white flowers arise from a black tuber about half an inch in diameter and four or five inches deep. Some are like our own species, while Drosera gigantea suggests a sea lavender with numerous small white flowers on a richly branched inflorescence that arises from a deeply seated black tuber of elongated form. This tuberous habit can be regarded as a means of evasion of the climatic extremes, and can hence be compared with the annual habit so well exemplified by the ephemeral Compositæ of the desert areas that compass their whole life-history in a few weeks after the infrequent rains. These composites paint the desert like a Joseph's coat of many colours, and not the least interesting feature is the marked dominance of one species over a considerable area, so that you may get square miles looking white with the presence of Helipterum niveum, while farther on are acres which are yellow or red through the dominance of other species. What the factors are which determine this dominance is uncertain. Very often there is no obvious soil difference to account for this. Like most desert annuals, the Australian species are short-lived plants which germinate during appreciable rain and pass their whole life-history within a few weeks. If, as may well happen, no appreciable rain falls, the seeds remain dormant until conditions become more suitable; but the abundance of these annuals bears witness to the relative fertility of the soil and to the limiting conditions upon vegetation which are imposed by the vagaries of the climate.

The sandy coastal plains are chiefly characterized by their poor soils, consisting of alluvial deposits so notoriously deficient in nutrient salts as to produce herbage inadequate for the support of healthy sheep and stock and responsible for the coastal diserses. We now know that these are the outcome of deficiencies, especially in the trace elements copper, zinc and cobalt. The last, though only requisite in amounts measured in parts per ten million of the food eaten, is now known to be essential to the well-being of ruminants, while zinc and copper are, in amounts of similar diminitude, essential alike to plant growth and animal welfare. The spraying of spruce trees with very dilute solutions of zinc sulphote has a most spectacular effect on the rate of growth of this tree on these soils. This response is indicative of the influence that such deficiencies may exert on competition on one hand between species that are tolerant of meagre rations of these trace elements or particularly efficient in their appropriation from inadequate supplies, and, on the other, those species that make greater demands for such upon the soil or are perhaps less efficient in their exploitation.

Not the least interesting feature of the Australian. flora is the way in which species after species introduced from the Mediterranean or South Africa has. 'run amok' in those areas where man has disturbed. the natural vegetation.

It is possibly true in Australia, as the late Dr. Cockayne said of New Zealand, that the native.species: are quite capable of holding their own against introductions exeept where man disturbs the natural conditions. The native species are, in fact, specialists, peculiarly fitted to the natural environment. But certain it is that in the areas occupied by man or materially disturbed by him the introductions have established themselves in Australia in a most spectacular way. Near Humbug Scrub, not far from Adelaide, one can see many acres of pasture almost completely occupied by the globe artichoke, which, beautiful though they are in flower, are apparently of little value. Again, the Mediterranean bugle, Echium plantagineum, has been encouraged in some of the arid areas as providing fodder during the dry season, and here it rejoices in the name of "Salvation Jane"; but one sees potentially good pastures ruined by its superabundance in the region of Port Augustus, and here it is called "Patterson's Curse" ! The many acres which it there covers with its blue flowers are to the mere visitor a charming sight. Again, the South African Oxalis cernua was introduced into Australia as a garden plant and was at one time sold at $4 s .6 d$. a root. To-day one can see citrus orchards in which the whole of the ground among the citrus trees is one continual sheet of yellow with its brilliant flowers, and soursop, as it is called, has likewise become a pest in many parts. To-day, too, one can see in southern Western Australia the arum lily (Richardia) occupying the ditches, and tall species of Watsonia, constituting what might almost be described as thickets, and species of Homeria rendering poisonous the pastures they infest. It is no wonder that Australians to-day hesitate to grow even the most beautiful of the South African plants for fear they should get out of hand and become one more pest added to the unwelcome invaders. One has only to see the swamps in Western Australia invaded by arum lilies or the exuberant species of Watsonia to realize how easily erstwhile garden plants can become a curse.

If we consider the flora of West Australia in its wider aspects we cannot but be struck by the fact that it is at once highly specialized, but small and restricted in character in relation to the area involved. Despite its million square miles the total vascular flora numbers only about 5,800 species. It is true that much of Western Australia is desert; but a large part of this carries its own specialized flora. To apprehend the relative paucity it is sufficient to state that the whole of France with scarcely one-fifth 
of the area of Western Australia has a flora containing nearly five thousand species or roughly five-sixths, and comprising a far greater diversity of genera. The flora of France comprises more than 884 genera compared with only about 560 genera in the flora of Western Australia. Still more significant is that South Africa, with a similar area to Western Australia, has more than twice the number of genera. Isolation has thus on one hand permitted a high degree of specialization; but this has progressed in a much less varied biological community than would obtain in an area that had not been isolated and may well account in large measure for the vulnerability of the Western Australian flora to competition from immigrants when conditions of their environment are changed.

\section{NEWS and VIEWS}

Physics at Queen's University, Kingston, Ontario : Prof. J. K. Robertson

AFTER forty years of faithful and constructive service, Prof. John Kellock Robertson, head of the Department of Physics at Queen's University, Kingston, Ontario, has resigned. Prof. Robertson was born in Perth, Ontario, in 1885. He attended the local schools and entered the University of Toronto, where he graduated in 1907, and later served as demonstrator in the Department of Physics. He was appointed lecturer in physics at Queen's University in 1909, and except for two years when he was absent at Cambridge during 1912-13 and at the Imperial College of Science and Technology, London, as visiting professor during 1933-34, he has worked there ever since, becoming head of the Department in 1943. He received the degree of doctor of laws at the spring convocation this year at Queen's. For many years he was a member of the Faculties of Arts, Engineering and Medicine-something almost unique in Queen's administration. His lectures on optics were well known, but he achieved the greatest distinction in his courses for medical students. He was elected a Fellow of the Royal Society of Canada in 1926, served as secretary of Section III for several years and was elected president of that Section in 1942-43; finally, in 1944, he was elected president of the Society.

During his long career, Prof. Robertson has found time to write many papers and books. Among the books should be mentioned a volume on physical optics which appeared in 1929 and has gone through three editions. This is an exceptionally readable and comprehensive text and is a very useful introduction to the subject. His book on X-rays and X-ray equipment is designed primarily for medical students and practitioners. Of a less formal character is a charming little book entitled "Atomic Artillery", the title of which tells its scope. His research interest, as shown by numerous papers, has been in the field of discharges in gases and vapours excited by high. frequency and micro-waves. For many years he served on the editorial board of Queen's Quarterly and has contributed articles to this and other journals. Prof. Robertson will be remembered by many graduates as an enthusiastic and inspiring teacher. Those who were fortunate enough to work with him in his own laboratory have been profoundly impressed and form a group of progressive and resourceful young physicists. In his retirement he has left Canada to live with his daughter, who has resided in London for a number of years.

Prof. B. W. Sargent, M.B.E.

Dr. B. W. Sargent, who is succerding Prof. J. K. Robertson, leaves the post of assistant director of the Physics Subdivision, Atomic Energy Project, Chalk River, Ontario. Born at Williamsburg,
Ontario, in 1906, Dr. Sargent received his early education in local schools and at Queen's University, where he obtained his B.A. in 1926 and M.A. in 1927. Following graduation, he spent two years at Queen's doing research in radioactivity under the direction of Prof. J. A. Gray, Chown research professor. The award of an 1851 Exhibition Scholarship in 1928 enabled him to spend the next two years at Cambridge, where he continued research in radioactivity at the Cavendish Laboratory under Lord Rutherford. His work there on beta-ray spectra and related problems led to an important relation known as Sargent's Law. In 1930 he returned to Canada as a lecturer in physics at his alma mater. For the next thirteen years he combined teaching duties with research so successfully that in 1941 he was elected a Fellow of the Royal Society of Canada. In 1943 he was granted leave of absence to join the Atomic Energy Project, Montreal Laboratory, under the National Research Council of Canada. Resigning from the staff of Queen's University in 1946, he has remained with this group until the present time; during 1945-50 he was head of the Nuclear Physics Branch, first at Montreal, then at Chalk River, and since January 1, 1951, he has been assistant director of the Physics Subdivision there. Dr. Sargent is an authority on problems relating to noutrons and to heavy-water piles, and has published papers on these and other subjects.

\section{U.S. Navy Aviation Medical Acceleration Labora- tory: Prof. Robert F. Rushmer}

THE University of Pennsylvania and the U.S. Naval Air Development Center at Johnsville, Bucks County, Pa., have announced the appointment of Dr. Robert F. Rushmer, of the University of Washington, Seattle, Washington, to be superintendent of the Scientific Department at the new Aviation Medical Acceleration Laboratory of the U.S. Navy. This Laboratory is one of the five laboratories of the Naval Air Development Center, which has made an agreement with the University of Pennsylvania whereby there is to be mutual exchange of personnel and facilities between the two institutions. Dr. Rushmer has also been appointed professor of applied physiology in the Faculty of Medicine, University of Pennsylvania; others appointed to the Aviation Medical Acceleration Laboratory will also receive appropriate faculty appointments in the University. The new Laboratory is at Johnsville, approximately eighteen miles north-east of Philadelphia, and its main functions will be the study by naval and givilian medical authorities of man's reactions to acceleration under conditions closely resembling the stress patterns encountered in actual air combat. The Laboratory has been designed as a complete aero-medical laboratory, well equipped for work in physiology, animal surgery, radioactivity, biophysics, biochem- 